\title{
Short communication: Genotypic and phenotypic identification of environmental streptococci and association of Lactococcus lactis ssp. lactis with intramammary infections among different dairy farms
}

\author{
B. Werner, ${ }^{*}$ P. Moroni, ${ }^{\dagger} \dagger^{1}$ G. Gioia, ${ }^{*}$ L. Lavín-Alconero,‡ A. Yousaf,§ M. E. Charter,\# B. Moslock Carter,\# \\ J. Bennett,II D. V. Nydam, ${ }^{*}$ F. Welcome, ${ }^{*}$ and Y. H. Schukken \\ ${ }^{*}$ Cornell University, Animal Health Diagnostic Center, Quality Milk Production Services, Ithaca, NY 14853 \\ †Università degli Studi di Milano, Dipartimento di Scienze Veterinarie per la Salute, la Produzione Animale e la Sicurezza Alimentare, \\ Via Celoria 1020133 Milan, Italy \\ łUniversity of Leon, Food Hygiene and Food Microbiology Department, Faculty of Veterinary Science, \\ Campus Universitario Vegazana s/n. 24071-León, Spain \\ §Department of Clinical Sciences, Faculty of Veterinary and Animal Sciences, PMAS Arid Agriculture University Rawalpindi, Pakistan \\ \#Keseca Veterinary Clinic, Geneva, NY 14456 \\ IINorthern Valley Dairy Production Medicine Center, MN 55964 \\ IGD Animal Health, Arnsbergstraat 7, 7418 EZ Deventer, the Netherlands
}

\section{ABSTRACT}

Lactococcus species are counted among a large and closely related group of environmental streptococci and streptococci-like bacteria that include bovine mastitis pathogenic Streptococcus, Enterococcus, and Aerococcus species. Phenotypic and biochemical identification methods can be inaccurate and unreliable for species within this group, particularly for Lactococcus spp. As a result, the incidence of Lactococcus spp. on the farm may have been historically underreported and consequently little is known about the clinical importance of this genus as a mastitis pathogen. We used molecular genetic identification methods to accurately differentiate 60 environmental streptococci and streptococcilike bacteria isolated from cows with high somatic cell count and chronic intramammary infection (IMI; $>2$ somatic cell scores above 4) among 5 geographically distinct farms in New York and Minnesota that exhibited an observed increase in IMI. These isolates were phenotypically identified as Streptococcus uberis and Streptococcus spp. Genetic methods identified 42 isolates (70\%) as Lactococcus lactis ssp. lactis, including all 10 isolates originally phenotypically identified as Streptococcus uberis. Antibiotic inhibition testing of all Lc. lactis ssp. lactis showed that 7 isolates were resistant to tetracycline. In the present study, a predominance of Lc. lactis ssp. lactis was identified in association with chronic, clinical bovine IMI among all 5 farms and characterized antimicrobial resistance for treatment therapies. Routine use by mastitis testing labs of molecular identification methods for environ-

Received May 2, 2014.

Accepted August 12, 2014.

${ }^{1}$ Corresponding author: pm389@cornell.edu mental streptococci and streptococci-like bacteria can further define the role and prevalence of Lc. lactis ssp. lactis in association with bovine IMI and may lead to more targeted therapies.

Key words: streptococci-like bacteria, Lactococcus lactis ssp. lactis identification, Streptococcus spp., bovine intramammary infection

\section{Short Communication}

Environmental streptococci and streptococci-like bacteria are significant contributors to the incidence of clinical mastitis in the United States (Gröhn et al., 2004), accounting for up to $15 \%$ of cows diagnosed annually (NMC, 1990). Only a small percentage of these infections become chronic (18\% of infections exceeding $100 \mathrm{~d}$ ), and although the cure rate for these cases is low, targeted therapy can sometimes reduce disease severity (Jones and Swisher, 2009).

Streptococcus uberis has been implicated in most bovine IMI, with less than $18 \%$ of reported cases attributed to other environmental streptococci and streptococci-like bacteria (Jones and Swisher, 2009). Among this $18 \%$, species of Enterococcus and Aerococcus have been well characterized in terms of incidence and role in bovine IMI; however, similar data for Lactococcus spp. are few (Malinowski et al., 2003; Kuang et al., 2009; Plumed-Ferrer et al., 2013). This lack of information could be attributed to limitations in routine procedures used to speciate environmental streptococci and streptococci-like bacteria. Phenotypic and biochemical tests recommended by the National Mastitis Council for identification of environmental streptococci and streptococci-like bovine milk isolates (NMC, 1999), as well as commercially available biochemical test kits for 
these microorganisms, are not inclusive of Lactococcus spp. and can produce variable or erroneous results that cause misidentifications (Fortin et al., 2003; Odierno et al., 2006; Svec and Sedlácek, 2008; Gordoncillo et al., 2010). Thus, it is possible that the incidence of Lactococcus spp. associated with bovine IMI has been severely underreported.

In recent years, molecular genetic methods such as PCR and sequencing-based methods have proven a more reliable means of accurately differentiating environmental streptococci and streptococci-like bacteria isolated from bulk tank and composite milk samples (Holm et al., 2004; Reinoso et al., 2010; de Garnica et al., 2014; Kanyó and Nagy, 2014) and have, in some cases, enabled the unequivocal identification of pure cultures of Lactococcus lactis ssp. lactis and Lactococcus garvieae originating from bovine IMI cases (Devriese et al., 1999; Kuang et al., 2009).

The objective of this report was to use molecular genetic identification methods to accurately differentiate environmental streptococci and streptococci-like bacteria isolated from cows with high SCC and chronic IMI among 5 geographically distinct farms in New York and Minnesota that exhibited an observed increase of IMI due to these bacteria. Where Lc. lactis ssp. lactis isolates were identified, antimicrobial resistance profiles were determined to contribute to the understanding of possible therapies and cure rates.

Isolates were included from 3 New York State dairy farms (herds A, B, and C), where each herd exhibited a high prevalence of chronic infections as determined by 2 or more consecutive monthly test-day linear scores greater than 4.0 (SCC $\geq 200,000$ cells $/ \mathrm{mL} ; 18,21$, and $23 \%$ of the total of lactating cows, respectively). Herd A, a 160-lactating cow Holstein Friesian herd in freestall facilities bedded with sand, had an average daily milk production of $40.1 \mathrm{~kg}$ and a rolling bulk milk SCC of 286,000 cells/mL. Quarter samples $(\mathrm{n}=42)$ from 12 cows with high SCC were submitted to the Quality Milk Production Services (QMPS; Ithaca, NY) for bacteriological culture. Ten of the 12 culture-positive samples were identified as Streptococcus spp. Isolates from herds B and $\mathrm{C}$ were submitted through a private veterinary clinic located in New York State and were initially identified as Streptococcus spp. or Streptococcus uberis. Herd B, an 895-lactating cow Holstein-Friesian herd in freestall facilities bedded with sand, had an average daily milk production of $40.2 \mathrm{~kg}$ and a bulk milk SCC of 397,000 cells $/ \mathrm{mL}$. Eighteen isolates from 11 cows with high SCC milk were submitted to QMPS for sequence analysis. Herd C, a 230-lactating cow Holstein-Friesian herd in a freestall facility bedded with sand, had an average daily milk production of $37 \mathrm{~kg}$ and bulk milk SCC of 286,000 cells/mL. Eleven isolates from 11 cows with high SCC milk were submitted to QMPS for sequence analysis.

Milk samples from 2 Minnesota dairy farms (herds $\mathrm{D}$ and $\mathrm{E}$ ) with chronic infection rates of 14 and $21 \%$, respectively, were also submitted for speciation of the pathogens. Herd D, a 1,693-lactating cow HolsteinFriesian herd in a freestall facility bedded with recycled sand, had an average daily milk production of $43 \mathrm{~kg}$ and a bulk tank SCC of 270,000 cells/mL. Eleven isolates from 11 cows with high SCC milk were submitted to QMPS for sequence analysis. Herd E, a 914-lactating cow Holstein-Friesian herd in a freestall facility bedded with recycled sand and sand lane, had an average daily milk production of $39 \mathrm{~kg}$ and a bulk tank SCC of 365,000 cells $/ \mathrm{mL}$. Ten isolates from 10 cows with high SCC milk were submitted to QMPS for sequence analysis.

The initial phenotypic speciation by all laboratories was performed using National Mastitis Council laboratory identification procedure recommendations (NMC, 1999). These biochemical and serological tests, including Gram stain, $\beta$-hemolysis, catalase test, esculin hydrolysis, Christie, Atkins, Munch-Petersen (CAMP) test, growth in enterococcal medium, and growth in $6.5 \% \mathrm{NaCl}$, were used to identify isolates as Streptococcus spp. or Streptococcus uberis. For 2 isolates, the BBL Crystal Gram-Positive ID Kit (Becton Dickinson, Franklin Lakes, NJ) was used for further identification. Polymerase chain reaction and sequence analysis of $16 \mathrm{~S}$ rDNA and rpoB were used for molecular identification of all isolates. For these analyses, a crude cell DNA lysate was first prepared for each isolate (Furrer et al., 1991). Briefly, pure culture streaks were made on a tryptic soy agar with $5 \%$ sheep blood plate (Becton Dickinson) and incubated for 18 to $24 \mathrm{~h}$ at $37^{\circ} \mathrm{C}$. One isolated colony was transferred to a 1.5-mL tube of Todd Hewitt Broth (Becton Dickinson) and incubated 18 to $24 \mathrm{~h}$ at $37^{\circ} \mathrm{C}$. A NanoDrop ND-1000 spectrophotometer (NanoDrop Technologies, Wilmington, DE) was used to determine DNA quantity. Two hundred fifty microliters of each broth culture was transferred to 1.5-mL microcentrifuge tubes and centrifuged to pellet for $10 \mathrm{~min}$ at $6,000 \times$ $g$ at room temperature $\left(20^{\circ} \mathrm{C} \pm 2^{\circ} \mathrm{C}\right)$. The supernatant was removed and discarded, and the pellet was resuspended in $95 \mu \mathrm{L}$ of $1 \times$ PCR buffer (Roche Applied Science, Indianapolis, IN). A $4-\mu \mathrm{L}$ aliquot of freshly prepared $50 \mathrm{mg} / \mathrm{mL}$ lysozyme (Promega, Madison, WI) solution was added to this suspension and mixed well by pipetting to result in a final concentration of 2 $\mathrm{mg} / \mathrm{mL}$ lysozyme. After a 15 -min incubation at room temperature, $1 \mu \mathrm{L}$ of a $20 \mathrm{mg} / \mathrm{mL}$ proteinase $\mathrm{K}$ solution (Promega) was added and vortexed to mix, resulting in a final concentration of $200 \mu \mathrm{g} / \mathrm{mL}$ proteinase $\mathrm{K}$. The tubes were incubated for up to $2 \mathrm{~h}$ in a heat block set 
at $58^{\circ} \mathrm{C}$ until the lysates cleared. The enzymes were inactivated for $8 \mathrm{~min}$ at $95^{\circ} \mathrm{C}$. After equilibrating to room temperature, tubes were centrifuged for $3 \mathrm{~s}$ at $6,000 \times$ $g$ to remove condensate from the sides and lids. Crude cell lysates were stored at $-20^{\circ} \mathrm{C}$ until further analysis.

Two different PCR amplification steps were performed to amplify 2 different gene targets, rpoB (Drancourt et al. 2004) and 16S rDNA (Greisen et al., 1994). Primers $\operatorname{rpoBF}$ (5'-AARYTIGGMCCTGAAGAAAT-3'), rpoBR (5'-GCCTTTAACTTCAGACTTATCA-3'), DG74 (5'-AGGAGGTGATCCAACCGCA-3'), and P5SH (5'-TGAAGAGTTTGATCMTGGCTCAG-3') were purchased from Integrated DNA Technologies (IDT, Coralville, IA). A PCR amplification mix was prepared consisting of $0.25 \mu \mathrm{L}$ of a $100 \mu M$ solution of each forward and reverse primer, $25.00 \mu \mathrm{L}$ of GoTaqGreen (Promega), 27.50 $\mu \mathrm{L}$ of $\mathrm{H}_{2} \mathrm{O}$, and $2.0 \mu \mathrm{L}$ of DNA. The mix was amplified on a MyCycler Thermal Cycler (Bio-Rad, Hercules, CA) with running conditions of an initial denaturation step of 5 min at $94^{\circ} \mathrm{C}$; 35 cycles of $30 \mathrm{~s}$ at $94^{\circ} \mathrm{C}, 30 \mathrm{~s}$ at $50^{\circ} \mathrm{C}$, and $1 \mathrm{~min}$ at $72^{\circ} \mathrm{C}$; and a final 7 -min extension time at $72^{\circ} \mathrm{C}$. The PCR amplicons were analyzed by gel electrophoresis to confirm a 740-bp rpoB amplicon and a 1,040-bp $16 \mathrm{~S}$ rDNA amplicon.

In preparation for sequencing, excess primers and nucleotides were removed from each sample by treatment with ExoSAP-IT (USB Corporation, Cleveland, $\mathrm{OH}$ ). Sequencing of each sample was performed in 2 directions using Big Dye Terminator chemistry on an ABI Prism 3700 DNA analyzer (Applied BioSystems, Foster City, CA). Sequences were proofread in SeqMan (version 5.08, Lasergene; DNAStar Inc., Madison, WI), compared with publicly available sequence data using the National Center for Biotechnology Information (NCBI) BLAST programs (Altschul et al., 1997), and identified using interpretive criteria provided by the Clinical and Laboratory Standards Institute (CLSI, 2008a). Briefly, the criteria for BLAST were as follows: maximum identity $\geq 99.0 \%$ to species level with greater than $0.8 \%$ separation between different species and an expected value $($ E-value $)=0.0$.

Antimicrobial MIC for Lc. lactis ssp. lactis isolates were determined using the Sensititer Mastitis Plate Format veterinary panel and Sensititer ARIS system (Trek Diagnostics Systems, Cleveland, OH). This panel includes antibiotics and the respective MIC dilution ranges listed in Table 1. Results were interpreted according to the European Food Safety Authority (EFSA) technical guides (European Commission, 2005, 2008).

Genotypic and phenotypic identification results for all isolates analyzed are shown in Table 2. Sequence analysis of all 60 isolates among the 5 herds identified overall $42(70 \%)$ as Lc. lactis ssp. lactis, $10(17 \%)$ as

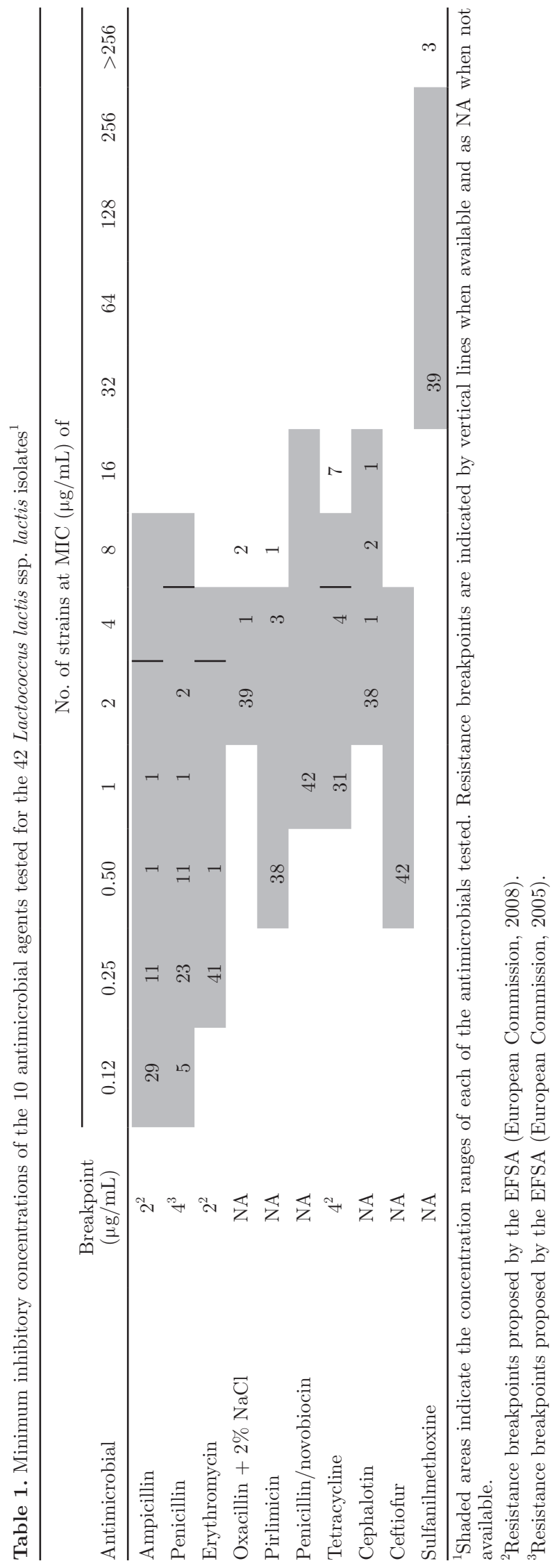


Table 2. Phenotypic identities and sequencing results for bacterial isolates from 5 farms (herds A, B, C, D, and E)

\begin{tabular}{|c|c|c|c|c|}
\hline $\begin{array}{l}\text { Herd } \\
\text { identity }\end{array}$ & $\begin{array}{c}\text { No. of } \\
\text { isolates }\end{array}$ & Isolate & $\begin{array}{l}\text { Phenotypic } \\
\text { identification }\end{array}$ & Sequencing result \\
\hline A & 10 & $\begin{array}{l}\mathrm{B}_{4}-261 \\
\mathrm{~B}_{4}-262 \\
\mathrm{~B}_{4}-263 \\
\mathrm{~B}_{4}-264 \\
\mathrm{~B}_{4}-265 \\
\mathrm{~B}_{4}-266 \\
\mathrm{~B}_{4}-267 \\
\mathrm{~B}_{4}-268 \\
\mathrm{~B}_{4}-269 \\
\mathrm{~B}_{4}-270\end{array}$ & $\begin{array}{l}\text { Streptococcus spp. } \\
\text { Streptococcus spp. } \\
\text { Streptococcus spp. } \\
\text { Streptococcus spp. } \\
\text { Streptococcus spp. } \\
\text { Streptococcus spp. } \\
\text { Streptococcus spp. } \\
\text { Streptococcus spp. } \\
\text { Streptococcus spp. } \\
\text { Streptococcus spp. }\end{array}$ & $\begin{array}{l}\text { Lactococcus lactis } \mathrm{ssp} \text {. lactis } \\
\text { Lactococcus lactis } \mathrm{ssp} \text {. lactis } \\
\text { Lactococcus lactis } \mathrm{ssp} \text {. lactis } \\
\text { Lactococcus lactis } \mathrm{ssp} \text {. lactis } \\
\text { Lactococcus lactis } \mathrm{ssp} \text {. lactis } \\
\text { Lactococcus lactis } \mathrm{ssp} \text {. lactis } \\
\text { Lactococcus lactis } \mathrm{ssp} \text {. lactis } \\
\text { Enterococcus faecium } \\
\text { Lactococcus lactis } \mathrm{ssp} \text {. lactis } \\
\text { Lactococcus lactis } \mathrm{ssp} \text { lactis }\end{array}$ \\
\hline B & 18 & $\begin{array}{l}\mathrm{B}_{4}-203 \\
\mathrm{~B}_{4}-204 \\
\mathrm{~B}_{4}-205 \\
\mathrm{~B}_{4}-206 \\
\mathrm{~B}_{4}-207 \\
\mathrm{~B}_{4}-208 \\
\mathrm{~B}_{4}-209 \\
\mathrm{~B}_{4}-210 \\
\mathrm{~B}_{4}-211 \\
\mathrm{~B}_{4}-212 \\
\mathrm{~B}_{4}-213 \\
\mathrm{~B}_{4}-214 \\
\mathrm{~B}_{4}-215 \\
\mathrm{~B}_{4}-216 \\
\mathrm{~B}_{4}-217 \\
\mathrm{~B}_{4}-218 \\
\mathrm{~B}_{4}-219 \\
\mathrm{~B}_{4}-220\end{array}$ & $\begin{array}{l}\text { Streptococcus uberis } \\
\text { Streptococcus spp. } \\
\text { Streptococcus spp. } \\
\text { Streptococcus spp. } \\
\text { Streptococcus spp. } \\
\text { Streptococcus uberis } \\
\text { Streptococcus uberis } \\
\text { Streptococcus uberis } \\
\text { Streptococcus uberis } \\
\text { Streptococcus uberis } \\
\text { Streptococcus uberis } \\
\text { Streptococcus uberis } \\
\text { Streptococcus uberis } \\
\text { Streptococcus spp. } \\
\text { Streptococcus spp. } \\
\text { Streptococcus spp. } \\
\text { Streptococcus spp. } \\
\text { Streptococcus uberis }\end{array}$ & $\begin{array}{l}\text { Lactococcus lactis } \mathrm{ssp} \text {. lactis } \\
\text { Lactococcus lactis } \mathrm{ssp} \text { lactis } \\
\text { Enterococcus saccharolyticus } \\
\text { Enterococcus saccharolyticus } \\
\text { Lactococcus lactis } \mathrm{ssp} \text {. lactis } \\
\text { Lactococcus lactis } \mathrm{ssp} \text {. lactis } \\
\text { Lactococcus lactis } \mathrm{ssp} \text {. lactis } \\
\text { Lactococcus lactis } \mathrm{ssp} \text {. lactis } \\
\text { Lactococcus lactis } \mathrm{ssp} \text { lactis } \\
\text { Lactococcus lactis } \mathrm{ssp} \text {. lactis } \\
\text { Lactococcus lactis } \mathrm{ssp} \text {. lactis } \\
\text { Lactococcus lactis } \mathrm{ssp} \text { lactis } \\
\text { Lactococcus lactis } \mathrm{ssp} \text { lactis } \\
\text { Enterococcus } \mathrm{spp} \text {. } \\
\text { Lactococcus lactis } \mathrm{ssp} \text {. lactis } \\
\text { Lactococcus lactis } \mathrm{ssp} \text { lactis } \\
\text { Lactococcus lactis } \mathrm{ssp} \text {. lactis } \\
\text { Lactococcus lactis } \mathrm{ssp} \text {. lactis }\end{array}$ \\
\hline $\mathrm{C}$ & 11 & $\begin{array}{l}\mathrm{B}_{4}-279 \\
\mathrm{~B}_{4}-280 \\
\mathrm{~B}_{4^{-}}-281 \\
\mathrm{~B}_{4}-282 \\
\mathrm{~B}_{4^{-}}-283 \\
\mathrm{~B}_{4}-284 \\
\mathrm{~B}_{4^{-}}-285 \\
\mathrm{~B}_{4}-286 \\
\mathrm{~B}_{4}-287 \\
\mathrm{~B}_{4}-288 \\
\mathrm{~B}_{4}-289\end{array}$ & $\begin{array}{l}\text { Streptococcus spp. } \\
\text { Streptococcus spp. } \\
\text { Streptococcus } \mathrm{spp} . \\
\text { Leuconostoc spp. } \\
\text { Streptococcus } \mathrm{spp} . \\
\text { Streptococcus } \mathrm{spp} . \\
\text { Streptococcus } \mathrm{spp} . \\
\text { Aerococcus viridans } \\
\text { Streptococcus } \mathrm{spp} . \\
\text { Streptococcus } \mathrm{spp} . \\
\text { Streptococcus } \mathrm{spp} .\end{array}$ & $\begin{array}{l}\text { Lactococcus lactis ssp. lactis } \\
\text { Lactococcus lactis } \mathrm{ssp} \text {. lactis } \\
\text { Lactococcus lactis } \mathrm{ssp} \text {. lactis } \\
\text { Lactococcus lactis } \mathrm{ssp} \text {. lactis } \\
\text { Enterococcus saccharolyticus } \\
\text { Lactococcus lactis } \mathrm{ssp} \text {. lactis } \\
\text { Lactococcus lactis } \text { ssp. lactis } \\
\text { Enterococcus saccharolyticus } \\
\text { Lactococcus lactis } \mathrm{ssp} \text {. lactis } \\
\text { Lactococcus lactis } \mathrm{ssp} \text { lactis } \\
\text { Lactococcus lactis } \mathrm{ssp} \text { lactis }\end{array}$ \\
\hline $\mathrm{E}$ & 10 & $\begin{array}{l}\text { W1-896 } \\
\text { W1-897 } \\
\text { W1-898 } \\
\text { W1-899 } \\
\text { W1-900 } \\
\text { W1-901 } \\
\text { W1-902 } \\
\text { W1-903 } \\
\text { W1-904 } \\
\text { W1-905 }\end{array}$ & $\begin{array}{l}\text { Streptococcus spp. } \\
\text { Streptococcus spp. } \\
\text { Streptococcus spp. } \\
\text { Streptococcus spp. } \\
\text { Streptococcus spp. } \\
\text { Streptococcus spp. } \\
\text { Streptococcus spp. } \\
\text { Streptococcus spp. } \\
\text { Streptococcus spp. } \\
\text { Streptococcus spp. }\end{array}$ & $\begin{array}{l}\text { Streptococcus uberis } \\
\text { Lactococcus lactis } \\
\text { Lactococcus lactis } \mathrm{ssp} \text {. lactis } \\
\text { Enterococcus saccharolyticus } \\
\text { Enterococcus saccharolyticus } \\
\text { Streptococcus uberis } \\
\text { Lactococcus lactis } \mathrm{ssp} \text { lactis } \\
\text { Lactococcus lactis ssp. lactis } \\
\text { Lactococcus lactis } \mathrm{ssp} \text { lactis } \\
\text { Streptococcus uberis }\end{array}$ \\
\hline
\end{tabular}

Enterococcus saccharolyticus, 1 (1.5\%) as Enterococcus faecium, 1 (1.5\%) as Enterococcus spp., 4 (7\%) as Streptococcus uberis, 1 (1.5\%) as Lactococcus lactis, and $1(1.5 \%)$ as Streptococcus dysgalactiae ssp. dysgalactiae.
For herd A, 9 of the 10 isolates phenotypically reported as Streptococcus spp. were identified by sequencing as Lc. lactis ssp. lactis, whereas 1 was identified as Enterococcus faecium. For herd B, where 8 of the 18 
isolates were initially phenotypically identified as Streptococcus spp. and 10 of the isolates as Streptococcus uberis, 15 of these were identified by molecular methods as Lc. lactis ssp. lactis, 2 as Ent. saccharolyticus, and 1 as Enterococcus spp. All 10 of the isolates phenotypically identified as Streptococcus uberis were genetically identified as Lc. lactis ssp. lactis.

For herd C, 2 isolates were biochemically identified by the BBL Crystal Gram-Positive ID kit as Leuconostoc spp. and Aerococcus viridans. These isolates were identified by sequencing as Lc. lactis ssp. lactis and Enterococcus saccharolyticus, respectively. Among the remaining 9 isolates that were phenotypically identified as Streptococcus spp., 2 were identified by molecular methods as Enterococcus saccharolyticus and 7 as Lc. lactis ssp. lactis.

All isolates from herds D and E were initially phenotypically identified as Streptococcus spp. For herd D, DNA sequence analysis identified 5 as Lc. lactis ssp. lactis, 4 as Enterococcus saccharolyticus, 1 as Streptococcus uberis, and 1 as Streptococcus dysgalactiae ssp. dysgalactiae. For herd E, 4 of these isolates were identified by sequence analysis as Lc. lactis ssp. lactis, 1 as Lc. lactis, 3 as Streptococcus uberis, and 2 as Enterococcus saccharolyticus.

Antibiotic inhibition testing of all Lc. lactis ssp. lactis showed that all isolates were susceptible to ampicillin, erythromycin, and penicillin, and 7 isolates were resistant to tetracycline. These data are shown in Table 1. Results showed that, among these 5 farms, $L c$. lactis ssp. lactis was the predominant streptococci-like bacterium associated with bovine IMI and identified potential antimicrobial agents for therapy. Overall, use of phenotypic identification methods resulted in overreporting the incidence of Streptococcus uberis and did not provide discriminatory information about the incidence of other genera and species. In this case, phenotypic and biochemical identification produced erroneous results and failed to identify Lc. lactis ssp. lactis. From a clinical perspective, it is important to understand the role played by Lc. lactis ssp. lactis within the farm and, furthermore, to study the epidemiology in order to define the behavior of this potential mastitis pathogen and management of therapy decisions. Routine use of molecular methods for speciation of environmental streptococci and streptococci-like bacteria in association with chronic, clinical IMI will contribute to this understanding. Antimicrobial susceptibility profiling along with accurate identification will enable targeted and early intervention for reduction of chronic IMI.

\section{REFERENCES}

Altschul, S. F., T. L. Madden, A. A. Schäffer, J. Zhang, Z. Zhang, W Miller, and D. J. Lipman. 1997. Gapped BLAST and PSI-BLAST: A new generation of protein database search programs. Nucleic Acids Res. 25:3389-3402.

CLSI (Clinical and Laboratory Standards Institute). 2008a. Interpretive criteria for identification of bacteria and fungi by DNA target sequencing; approved guideline. CLSI document MM18-A. CLSI Wayne, PA.

de Garnica, M. L., J. A. Saez-Nieto, R. Gonzalez, J. A. Santos, and C. Gonzalo. 2014. Diversity of gram-positive catalase-negative cocci in sheep bulk tank milk by comparative $16 \mathrm{~S}$ rDNA sequence analysis. Int. Dairy J. 34:142-145.

Devriese, L. A., J. Hommez, H. Laevens, B. Pot, P. Vandamme, and F. Haesebrouck. 1999. Identification of aesculin-hydrolyzing streptococci, lactococci, aerococci, and enterococci from subclinical intramammary infections in dairy cows. Vet. Microbiol. 70:87-94.

Drancourt, M., V. Roux, P. E. Fournier, and D. Raoult. 2004. rpoB gene sequence-based identification of aerobic gram-positive cocci of the genera Streptococcus, Enterococcus, Gemella, Abiotrophia, and Granulicatella. J. Clin. Microbiol. 42:497-504.

European Commission. 2005. Opinion of the Scientific Panel on Additives and Products of Substances used in Animal Feed on the updating of the criteria used in the assessment of bacteria for resistance to antibiotics of human or veterinary importance. EFSA J. 223:1-12.

European Commission. 2008. Technical guidance prepared by the Panel on Additives and Products or Substances used in Animal Feed (FEEDAP) on the update of the criteria used in the assessment of bacterial resistance to antibiotics of human or veterinary importance. EFSA J. 732:1-15.

Fortin, M., S. Messier, J. Pare, and R. Higgins. 2003. Identification of catalase-negative, non-beta-hemolytic gram-positive cocci isolated from milk samples. J. Clin. Microbiol. 41:106-109.

Furrer, B., U. Candrian, C. Hoefelein, and J. Luethy. 1991. Detection and identification of Listeria monocytogenes in cooked sausage products and in milk by in vitro amplification of hemolysin gene fragments. J. Appl. Bacteriol. 70:372-379.

Gordoncillo, M. J. N., J. A. N. Bautista, M. Hikiba, I. G. Sarmago, and J. M. B. Haguingan. 2010. Comparison of conventionally identified mastitis bacterial organisms with commercially available microbial identification kit (BBL Crystal ID). Phil. J. Vet. Med. 47:54-57.

Greisen, K., M. Loeffelholz, A. Purohit, and D. Leong. 1994. PCR primers and probes for the $16 \mathrm{~S}$ rRNA gene of most species of pathogenic bacteria, including bacteria found in cerebrospinal fluid. J. Clin. Microbiol. 32:335-351.

Gröhn, Y. T., D. J. Wilson, R. N. Gonzalez, J. A. Hertl, H. Schulte, G. Bennett, and Y. H. Schukken. 2004. Effect of pathogen-specific clinical mastitis on milk yield in dairy cows. J. Dairy Sci. $87: 3358-3374$

Holm, C., L. Jepsen, M. Larsen, and L. Jespersen. 2004. Predominant microflora of downgraded Danish bulk tank milk. J. Dairy Sci 87:1151-1157.

Jones, G. M., and J. M. Swisher. 2009. Environmental streptococcal and coliform mastitis. Virginia Cooperative Extension Publication No. 404-234. http://pubs.ext.vt.edu/category/dairy-cattle.html.

Kanyó, I., and D. Nagy. 2014. Molecular identification key of the family Streptococcaceae. Acta Microbiol. Immunol. Hung. 61:27-48.

Kuang, Y., K. Tani, A. J. Synnott, K. Ohshima, H. Higuchi, H. Nagahata, and Y. Tanji. 2009. Characterization of bacterial population of raw milk from bovine mastitis by culture-independent PCRDGGE method. Biochem. Eng. J. 45:76-81.

Malinowski, E., A. Klossowska, M. Kaczmarowski, and K. Kuzma 2003. Prevalence of intramammary infections in pregnant heifers. Bull. Vet. Inst. Pulawy 47:165-170.

NMC (National Mastitis Council). 1990. Procedures for the identification of specific groups or species of microorganisms that cause 
mastitis. Microbiological procedures for the diagnosis of bovine udder infection. National Mastitis Council Inc., Washington, DC.

NMC (National Mastitis Council). 1999. Laboratory Handbook on Bovine Mastitis. Rev. ed. National Mastitis Council, Madison, WI.

Odierno, L., L. Calvinho, P. Traverssa, M. Lasagno, C. Bogni, and E. Reinoso. 2006. Conventional identification of Streptococcus uberis isolated from bovine mastitis in Argentinean dairy herds. J. Dairy Sci. 89:3886-3890.

Plumed-Ferrer, C., K. Uusikylä, J. Korhonen, and A. von Wright. 2013. Characterization of Lactococcus lactis isolates from bovine mastitis. Vet. Microbiol. 167:592-599.
Reinoso, E., S. Dieser, L. Calvinho, C. Bogni, and L. Odierno. 2010. Phenotyping and genotyping of streptococci in bovine milk in Argentinean dairy herds. Acta Vet. Hung. 58:287-295.

Svec, P., and I. Sedlácek. 2008. Characterization of Lactococcus lactis ssp. lactis isolated from surface waters. Folia Microbiol. (Praha) 53:53-56. 